\title{
PESAWAT TERBANG TANPA AWAK (PTTA) SEBAGAI PENGEMBANGAN MEDIA SISTEM INFORMASI GEOSPASIAL
}

\author{
Diyan Parwatiningtyas \\ Program Studi Informatika, Universitas Indraprasta PGRI \\ diyan_parwatiningtyas@unindra.ac.id,diane.tyas@gmail.com
}

Submitted April 1, 2019; Revised May 4, 2019; Accepted June 29, 2019

\begin{abstract}
Abstrak
Seperti kita ketahui, Indonesia memiliki struktur lapisan permukaan bumi yang dinamik. Perbedaan tingkat topografi ini mengakibatkan terjadinya variasi lahan dan berdampak pada meterial yang terkandung di dalamnya. Hal ini tentunya akan memperkaya kuantitas lahan pertambangan dan kekayaan vegetasi tanaman serta laut. Keseluruhannya merupakan sumber daya alam yang bermanfaat bagi keberlangsungan hidup manusia dan habitat lainnya. Dalam memonitoring pengelolaannya dari permukaan, diperlukan suatu metode yang berfungsi untuk menginformasikan keadaan wilayah potensial, salah satunya dengan Sistem Informasi Geospasial (SIG). Pada umumnya, pengambilan data SIG ini dapat diperoleh melalui foto udara citra satelit. Akan tetapi hasil yang ditampilkannya kurang akurat, sehingga dibutuhkan suatu instrumen yang dapat memetakan data SIG dengan lebih baik lagi, salah satunya dengan penerapan desain Pesawat Terbang Tanpa Awak (PTTA) atau biasa dikenal dengan drone. PTTA sendiri saat ini merupakan suatu teknologi yang berkembang dengan pesat. Pada kesempatan kali ini penulis akan memperkenalkan teknologi PTTA yang dapat didesain sendiri sesuai dengan kebutuhan, dan mampu menjawab setiap permasalahan yang berhubungan dengan pemetaan citra dari sistem informasi geospasial.
\end{abstract}

Kata Kunci : Variasi topografi, Penerapan teknologi PTTA, Pengembangan SIG.

\begin{abstract}
As we know, Indonesia has a dynamic structure of the earth's surface layer. This topographic differences level was results in land variations and it impacts on the material contained in it. This certainly will growth an enrich amount of natural land resources and the quality of plant vegetation and the sea. All of them are natural resources that are beneficial for human survival and the other habitats. To monitoring its management from the surface, we need a method that serves to inform the potential region conditions, one of them is the Geospatial Information System (GIS). Generally, taken data for GIS could be obtained through aerial photography of satellite images. However, the results are less accurate, so that, we look for the other alternatif instruments, which could made a GIS map better, using the design of unmanned aircraft vehicle (PTTA) or commonly known as drones. For now, Unmanmed Aircraft Vehicle is a currently technology which that is growing rapidly. On this occasion, the author will introduce UAV technology that can be designed by itself according to needed, and could be able to answer every problems in which related to image mapping from geospatial information systems.
\end{abstract}

Key Words : Topography variation, UAV applied technology, GIS development.

\section{PENDAHULUAN}

Indonesia merupakan wilayah yang memiliki struktur lapisan bumi dinamik, dan hal ini mengakibatkan terbentuknya variasi lahan yang berdampak pada keanekaragaman material yang terkandung didalamnya. Tidak heran jika Indonesia memiliki potensi sumberdaya alam yang banyak dan bermanfaat untuk kelangsungan hidup manusia dan habitat lainnya. Untuk menginformasikan tata kelola besarnya kuantitas produktif sumber daya alam dan variasi topografinya, sekaligus memonitoring kemungkinan area atau lahan yang mengalami longsor atau kebakaran hutan serta banjir dari permukaan diperlukan suatu sistem informasi pemetaan, salah satunya yaitu 
dengan sistem informasi geospasial (SIG). Pengambilan data SIG biasanya diperoleh dari foto udara. Terdapat dua type pengambilan foto udara : 1 . Foto udara yang diperoleh dari citra satelite 2. Foto udara yang diambil dari Pesawat Terbang Tanpa Awak/Nirawak (PTTA) atau drone [1]. Foto udara yang diperoleh melalui citra satelit, memiliki kelebihan yaitu mampu memetakan hasil lahan skala luas dan kountour gambar yang jelas. Akan tetapi ia memiliki kekurangan yaitu pengambilan gambar tidak dapat dilakukan saat siang hari, dan berawan. Kemudian saat pengambilan data, seringkali mengganggu sinyal telekomunikasi yang lain dan membutuhkan biaya yang mahal. [3]. Beda halnya dengan PTTA atau drone. Pengambilan foto udara dengan drone dapat diterbangkan dalam segala kondisi apapun dengan jangkauan ketinggian yang rendah sehingga tidak mengganggu sinyal radar pesawat atau telekomunikasi yang lain. Selain itu, biaya operasional pengambilan foto udara untuk pengolahan SIG dengan PTTA ini sangatlah terjangkau. Untuk itulah, melalui kegiatan penelitian ini, kita berupaya melaksanakan tindakan monitoring pemetaan SIG itu sendiri, melalui pengembangan teknologi instrumentasi yaitu Pesawat Terbang Tanpa Awak (PTTA)/drone berjenis UAV (Unmanned Aerial Vehicles) yang bertujuan untuk memonitoring suatu keadaan area tertentu yang memiliki kondisi potensial dari suatu lahan, tingkatan topografi, hingga area yang memiliki tingkat bencana yang besar, terutama kebakaran hutan, atau hot spot area yang memungkinkan terjadinya erupsi gunung api, area longsor/ banjir, yang mana area tersebut diamati dengan teknologi foto udara yang diterbangkan oleh UAV dari permukaan, sehingga kita mampu mengelola data pemetaan SIG ini lebih akurat, dan mampu memanagemen lingkungan secara lebih baik lagi.

\section{A. Pengertian PTTA UAV}

UAV yang merupakan kepanjangan dari Unmanned Aerial Vehicles", atau dalam kata lain "DRONE" adalah tipe pesawat terbang yang beroperasi dengan sendirinya tanpa seorang pilot atau awak pesawat di atas pesawat saat pesawat mengudara [2]. UAV saat ini semakin popular digunakan dalam berbagai jenis kegiatan. Di antaranya adalah pemanfaatan UAV sebagai Penjejakan Obyek (object tracking), pemetaan (mapping) untuk SIG yang berfungsi sebagai pengawasan, monitor area topografi lahan, area produktif kelapa sawit, tambang, dan lain sebagainya. Fotografi penggunaan UAV juga bermanfaat sebagai pemantau perairan, pantai bahkan pertahanan. Hal ini dipengaruhi karena adanya perkembangan teknologi dan perbedaan kebutuhan. Oleh karena itu, UAV dibuat khusus untuk suatu tugas atau fungsi tertentu yang membuat kemampuan UAV satu dengan lainnya berbeda. Quadcopter merupakan sebuah perangkat drone dengan empat balingbaling yang diatur dalam konfigurasi menyilang. Dua buah baling-baling berputar searah jarum jam dan dua buah baling-baling lainnya berlawanan. A.R Drone dapat dikendalikan menggunakan ponsel pintar atau perangkat sejenis yang memiliki sistem operasi melalui sinyal WIFI [2]. Teknologi Computer Vision memungkinkan pengambilan informasi dari suatu citra sebagai parameter atau referensi. Sebagian besar pemanfaatan citra didasari pada keterbatasan kemampuan sensor dalam kemampuannya mendeteksi sesuatu. Hal ini juga berkaitan pada efisiensi perangkat keras yang digunakan. Banyak metode dikembangkan demi mendapatkan kemampuan deteksi yang baik melalui citra sehingga data hasil ekstraksi dapat digunakan untuk keperluan komputasi lain. Salah satu permasalahan pemanfaatan citra sebagai sumber informasi adalah gangguan (noise) [3]. Jenis gangguan yang mempengaruhi citra 
adalah tingkatan terang/gelap, kualitas citra dan pergerakan. Sedangkan drone tidaklah demikian. Dalam penelitian ini akan dirancang PTTA UAV / Drone dengan atribut two exist stabily site gibal yang didesain secara khusus untuk memperoleh data yang akurat, real dan komprehensif, serta kamera multispectral yang mampu memberikan informasi yang tidak kasat mata, dalam bentuk spektrum warna [1].

\section{B. Jenis - Jenis UAV}

Jika dilihat dari konfigurasi airframe, UAV dapat dibedakan menjadi 2 jenis yaitu fixed-wing dan rotary-wing. Fixedwing merupakan UAV yang bentuk sayapnya merupakan sudah tetap dan merupakan komponen gerak dari pesawat tersebut, untuk jenis Rotary-wing merupakan UAV yang komponen geraknya berupa baling-baling yang berputar (rotor) [1]. Berikut adalah contoh fixed-wing dan rotary-wing:

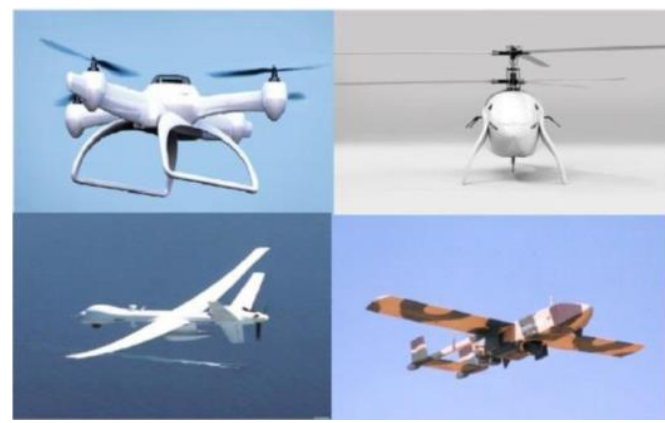

Gambar 1. Rotary Wing (Atas) dan Fixed-Wing (Bawah)

Secara umum sistem UAV dibentuk oleh beberapa bagian yang saling berinteraksi, seperti pesawat, dan stasiun kontrol bumi [2].

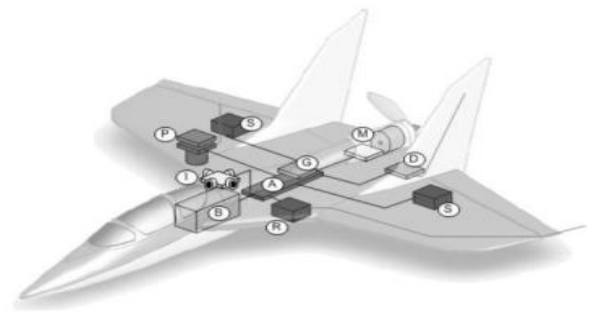

Gambar 2. Sistem UAV Secara Umum
Pesawat merupakan bagian terpenting dari UAV itu sendiri [2]. Adapun bagian penyusun pesawat dapat dilihat pada gambar 3 berikut ini :

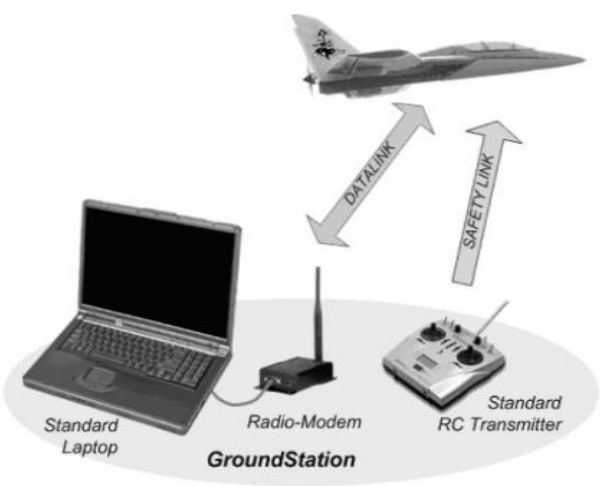

Gambar 3. Bagian-Bagian dari Pesawat Udara Tanpa Awak

Keterangan :

$A=$ Autopilot kontrol

$\mathrm{B}=$ Baterai

$\mathrm{D}=$ Datalink radio modem dan antena

$\mathrm{G}=$ Penerima GPS

$\mathrm{I}=$ Sensor IR

$\mathrm{M}=$ Motor dan kontrol

$\mathrm{R}=$ Penerima $\mathrm{RC}$ dan antena

$\mathrm{S}=$ Servo

$\mathrm{P}=$ Payload, kamera dan pemancar

Stasiun kontrol bumi terdiri darisebuah komputer, pemancar $\mathrm{RC}$, dan radio modem.

\section{Portable Ground Control Station pada PTTA}

Proses pengolahan data sistem informasi geospasial agar lebih akurat, tentunya didukung oleh Portable Ground Control System (PGCS) sebagai kelengkapan di PPTA. Tugas utamanya dari PGCS ini yaitu integrasi sub system baik hardware maupun software. Software GCS menangani proses pengumpulan atau menerima, memproses, mengirim dan menampilkan data - data penerbangan yang terkait dengan pemetaan SIG, dengan kontrol dan command data, video data, yang berasal dari Air Vehicle Unit yang dalam hal ini adalah PTTA/drone. Adapun 
data - data penting yang dapat membantu pilot dalam dalam mengendalikan atau mengawasi PTTA secara remote (manual) ataupun autonomous, harus ditampilkan secara grafis dengan menganut Graphical User Interface (GUI). Data tersebut adalah:

- Basic Control Instrument

- Artificial Horizon

- Turn Indicator

- Compass

- Ground speed dan air speed indicator

- Altimeter

- Warning and System Monitoring

- Batteries/Electrical Power Indicator

- Time

- Range

- Navigation

- GPS Waypoints Following

- GPS Position

- Operational Maps.

Data yang diterima oleh GCS berasal dari onboard system yang terinstall pada PTTA. Air data system diberikan oleh sensor pilot static untuk airspeed, AHRS unit untuk attitude dan heading, GPS untuk posisi, ground speed dan ketinggian dari MSL. Semua data ini diakuisisi, dikendalikan dan ditelemetrikan oleh sistem pengolah data yang berbasis microcontroller [1].

Sistem software harus mengakomodasi dua level mode yang ada pada saat penerbangan. Kedua level tersebut adalah : 1. Direct Controlling (Man in the loop). 2. Autopilot Mode [1]. Gambar 5 dibawah merupakan gambar dari Ground Control System :

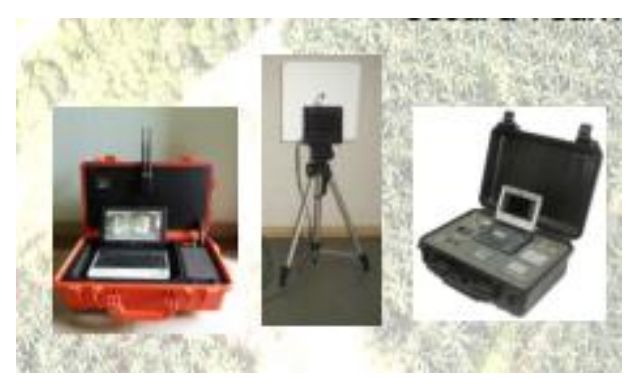

Gambar 4. Tampilan Instrument Ground Control System

\section{METODE PENELITIAN}

\section{Lokasi dan Waktu Penelitian}

Penelitian dilakukan di Jakarta dan Banten, dengan mengajak kerjasama dengan PT Ranatama (Citra Buana Data Prima) selama satu tahun, tahun periode tahun 2017 yang bersifat Research and Development $(R \& D)$, dengan menerapkan beberapa metode antara lain :

1. Mempersiapkan desain rancangan pesawat terbang tanpa awak untuk pengelolaan aerophotography, khususnya disini yaitu basis data Sistem Informasi Geospacial (SIG).

2. Membuat PTTA, dengan spesifikasi seperti gambar berikut :

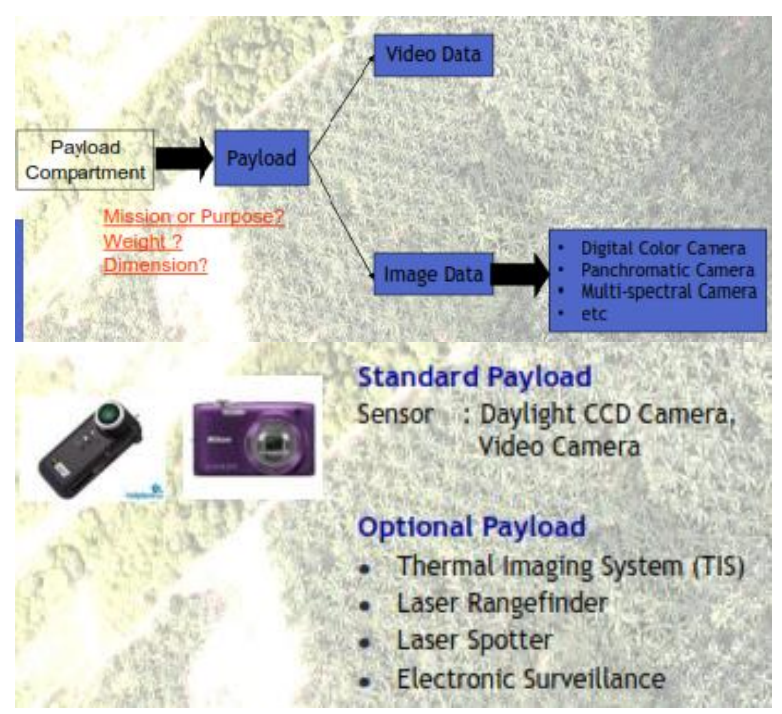

Gambar 5. Spesifikasi Muatan yang Terdapat di dalam PTTA untuk Keperluan Sistem Informasi Geospasial

PTTA dibuat dengan menggunakan kamera dan video khusus untuk keperluan aerophotography, yang memiliki keunggulan khusus yaitu :

1. SIG data service, yang meliputi :

- Parcel \& Cadastral Mapping.

- Utility Mapping - Electrical distribution, Telecom, Oil/Gas, Water / Sewer Network.

- Spatial Analysis. 
- GIS Data Conversion \& Digitization Navigation Map Production.

- Navigation Map Production.

- Image Processing.

- Georeferencing \& Rectification.

- Land use / land cover Mapping.

- High-resolution urban Mapping.

2. Tampilan Foto Udara yang menggunakan RGB (Red - Green - Blue) kamera dan video multispektral, yang nantinya akan menghasilkan tampilan pemetaan sebagai berikut :

- Peta foto udara yang sudah terkalibrasi dengan garis bujur dan lintang bumi.

- Peta topography DTM dan DEM.

- Peta kountour.

- Dense cloud/3D modelling.

3. Tampilan Photogrametry Mapping / Orto Photo yang terdiri dari :

- Aerial Triangulation.

- Softcopy Stereo (Planimetric/Vector

Compilation Extraction). Feature

- Digital Elevation/Terrain Modeling.

- Digital Ortho photo Production.

Drone yang dirancang bangun bekerja dengan optimal dan mampu merekam video dalam CinemaDNG dan Apple ProRes dan format umum lainnya ketika pasca-produksi dalam pembuatan Aerial Mapping. Juga mendukung format FAT32 / exFAT file sistem, yang memungkinkan menyalin file dengan cepat dan langsung dari CINESSD tanpa software tambahan.

\section{HASIL DAN PEMBAHASAN}

Setelah PTTA yang dirancang sesuai dengan metode penelitian selesai dibuat, barulah selanjutnya dilakukan proses pengambilan dan pemrosesan data untuk Sistem Informasi Geospasial (SIG). Adapun tahapan pengambilan adalah sebagai berikut :

\section{Persiapan dan Setting Camera}

- Persiapkan PTTA yang sudah dibuat.

- Cek battery Power dan SD Card.

- Cek ISO Speed dan Speed Shutter Camera pada menu setting.

- Cek dudukan kamera di pesawat.

- Pemasangan kamera di pesawat.

\section{Cek dudukan kamera di pesawat dan} Pemasangannya

- Pastikan dudukan kamera terpasang secara tepat pada UAV.

- Periksa pengikat dudukan kamera.

- Periksa servo dan kabelnya.

- Pastikan posisi kamera menghadap ke bawah.

- Pastikan kamera dalam posisi tidak mudah bergerak dalam dudukannya.

- Memeriksa fungsi servo penggerak (ambil sekali foto).

\section{Proses pengambilan data foto udara}

$>$ PTTA diterbangkan dan mulai memproses pengambilan data foto udara. Seperti diagram di gambar 6 berikut ini :

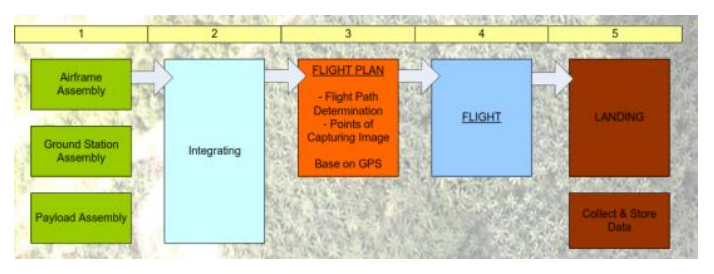

\section{Gambar 6. Proses Pengambilan Data pada Foto Udara}

$>$ Pada saat PTTA diterbangkan unsur sensor dan perangkat untuk merekam dan memoto udara dimulai, dan muncul kalibrasi dan deteksi input data besrta ketinggian dan besarnya kecepatan yang terlihat melalui portabel Ground Control System.

Adapun tampilannya adalah seperti gambar 7 di bawah ini : 


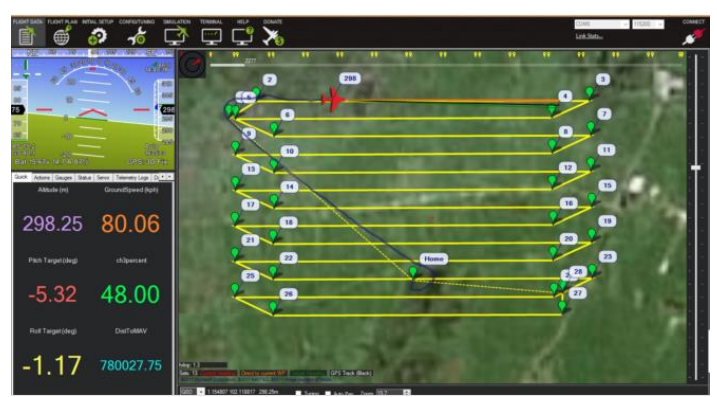

Gambar 7. Menampilkan gambar waypoint yang menandakan pesawat beroperasi dengan baik saat diterbangkan

\section{Mendownload foto hasil foto udara.}

Setelah pesawat selesai mendownload data di udara, baru kita mengambil data. Tahapannya adalah sebagai berikut :

- Melepas camera dari dudukan kamera di UAV.

- Membuka memory card kamera.

- Memasukkan ke card reader dan buka foldernya.

- Menyiapkan folder baru pada laptop.

- Mengcopy/cut file dari memory card dan letakkan dalam folder baru yang telah disiapkan.

Setelah proses pengambilan data selesai, baru data diproses ke sistem informasi geospasial dengan menggunakan software pemetaan khusus untuk SIG, biasa yang dipakai yaitu software microsoft ICE dan software tambahan lainnya seperti yang tertera pada gambar 8 berikut :

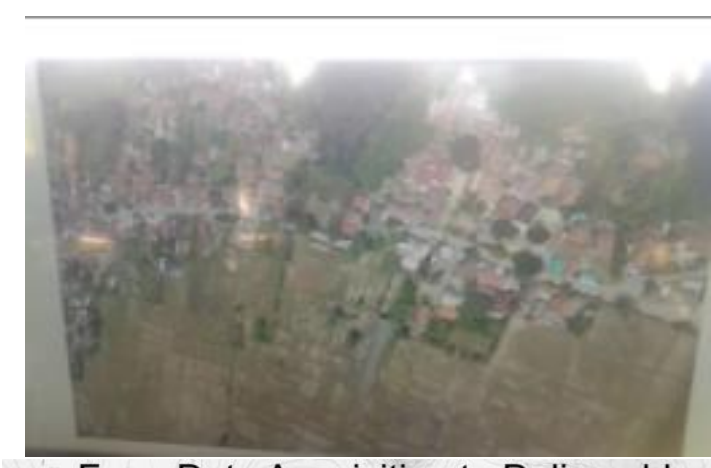

From Data Acquisition to Deliverables Operational Workflow

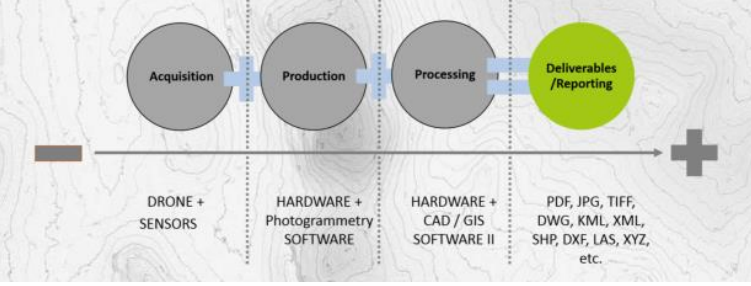

Gambar 8. Proses Akuisisi Data ke Proses SIG map

Adapun hasil dari foto citra yang diproses ke dalam peta SIG adalah sebagai berikut :

1. Ortophoto : yaitu hasil gambar yang didapat dari pengambilan sejumlah foto udara yang dirangkai menjadi satu dan disajikan ke sistem informasi geospasial. Melalui foto citra ini, tampilan wilayah dapat telihat secara jelas. Pemilik lahan dapat mengetahui seperti apa pemanfaatan lahan yang dimilikinya. Hasil peta dapat diupload ke dalam aplikasi google earth, sehingga tampilannya lebih jelas dan lebih jernih.

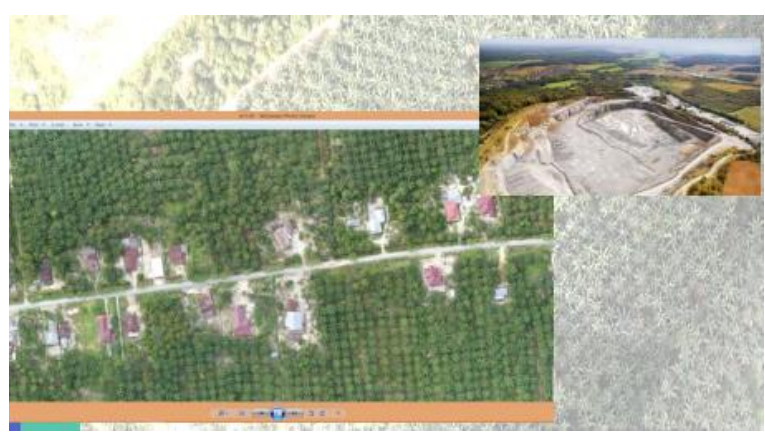

Gambar 9. Tampilan Hasil Orthophoto yang Diambil dari Samping dan Vertikal 
2. Peta lahan : Adalah orthopoto berbentuk peta digital yang dilengkapi dengan data terukur. Tampilan peta modelling secara 3D di atas lahan juga ditampilkan secara detail.

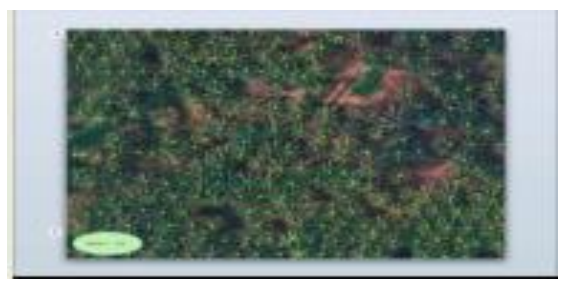

\section{Gambar 10. Contoh Tampilan Peta Lahan}

3. Tree Counting : Adalah aplikasi yang digunakan untuk menghitung jumlah pokok pohon dan mengetahui lebar tajuk setiap pohon secara cepat dan akurat. Pemilik lahan dapat memprediksi potensi kerugian apabila ditemukannya penggunaan lahan yang tidak sesuai dengan rencana yang telah ditetapkan.

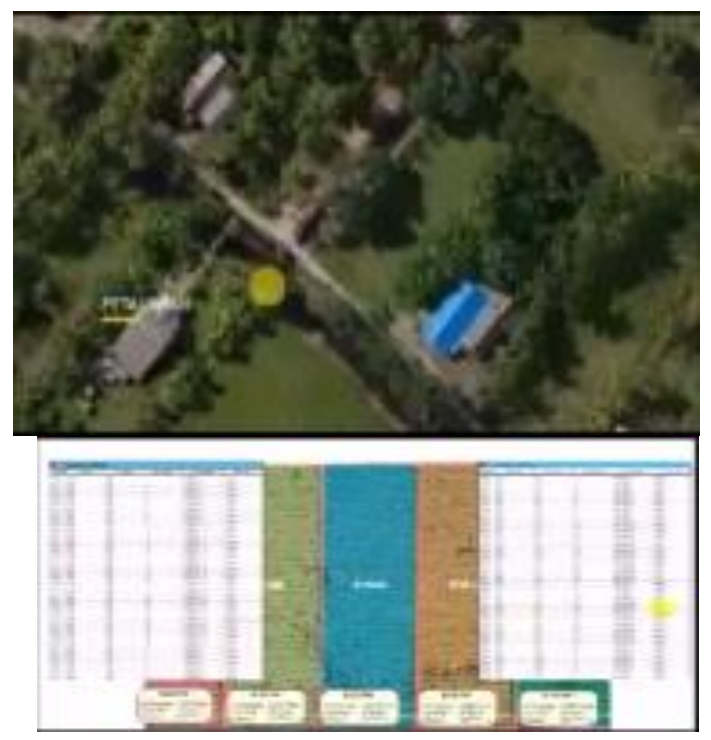

Gambar 11. Tampilan Tree Counting

\section{ERP (Enterprise Resources Planning)} Enterprise Resources Planning adalah informasi terintegrasi yang berfungsi untuk memanage lahan berdasarkan data - data yang dihasilkan oleh foto udara. Dengan sistem informasi ini, pemilik lahan dapat mengetahui informasi data softpile dan topography lahan beserta hasil analisisnya dalam waktu singkat. Pemantauannya dapat dilakukan secara online, sesuai kebutuhan. Dengan ERP, pemilik lahan dapat mengoptimalisasikan waktu dan sumber daya yang dimilikinya secara aman dan efisien.

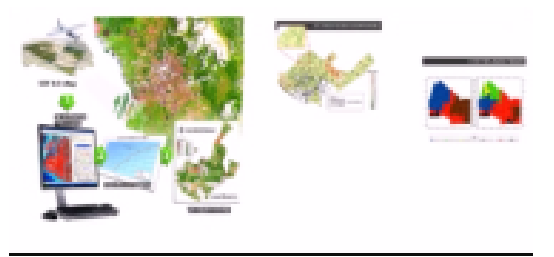

\section{Gambar 12. Tampilan tahapan ERP}

\section{SIMPULAN}

Berdasarkan hasil pembahasan diatas dapat diperoleh beberapa kesimpulan, antara lain:

1. Teknologi foto udara yang diterbangkan oleh PTTA UAV dari permukaan, mampu mengelola data pemetaan SIG ini lebih akurat, serta memanagemen lingkungan secara lebih baik, dengan metode yang mudah dan biaya yang terjangkau.

2. Hasil - hasil pemetaan SIG dari foto udara berupa Orthophoto, Peta lahan, Tree Counting serta Enterprise Resources Planning yang dapat diakses secara online, 
memudahkan pemilik lahan untuk menganalisis lahan secara produktif, dan efisien, sehingga dapat meminimalisir potensi kerugian dari sumber daya alam yang dimilikinya. Disamping itu, upaya pencegahan bencana alam juga dapat dilakukan,mengingat sistem pemetaan SIG melalui PTTA ini mampu mengidentifikasi hotspot kebakaran hutan maupun titik derajat panas di area pegunungan vulkanik, atau topography lempeng tektonik dari atas permukaan secara detail dan dengan akurasi yang baik.

\section{UCAPAN TERIMAKASIH}

Pada kesempatan ini, Penulis mengucapkan terimakasih yang sebesar besarnya kepada team PTTA dari PT. Ranatama yang telah memberikan bantuan berupa kerjasama penelitian dan proyek pengerjaan foto udara kepada Penulis. Semoga di kesempatan yang akan datang, kerjasama dan solidaritas yang dicapai senantiasa dapat ditingkatkan lebih baik lagi dibandingkan dari masa - masa sebelumnya.

\section{DAFTAR PUSTAKA}

[1] E. Adharian dan Team Workshop . Modul Workshop Pesawat Terbang Tanpa Awak, Pengenalan dan Pengembangan PTTA Sebagai Salah Satu Pilihan Tugas Akhir dan Karir. Jakarta, Ranatama Report Modul, April 2017.

[2] Prof G. Romeo : " ENFICA-FC: ENvironmentally Friendly Inter City Aircraft powered by Fuel Cells", EC-6FP2005-30779-AERO-1, Ott. 2006 - 09.

[3] Salim Rusli : Interpretasi Struktur geologi Zona Rembang dan RanduBlatung dengan menggunakan Foto Udara Citra Satelite JERS -1 SAR. Bahan Tugas Akhir, Prodi Teknik Geofisika, Fakultas Ilmu Kebumian dan Teknik Mineral, ITB, 2005. 